\title{
Variabel-variabel yang Memengaruhi Perilaku Prososial Indonesia Tahun 2017
}

\author{
(Variables Affecting Indonesia's Prosocial Behavior in 2017) \\ Hadziq Shubhan ${ }^{1 *}$, Suryanto Aloysius ${ }^{2}$ \\ ${ }^{1,2}$ Politeknik Statistika STIS \\ E-mail: ${ }^{1} \underline{211709722 @ \text { stis.ac.id, }}{ }^{2}$ suryanto@stis.ac.id
}

\begin{abstract}
ABSTRAK
Perilaku prososial penduduk Indonesia pada tahun 2017 mengalami penurunan dibandingkan tahun 2016. Penurunan ini diikuti dengan meningkatnya perilaku agresifitas di Indonesia pada tahun 2017. Jika hal ini tidak segera ditangani, akan menjadi salah satu pemicu meningkatnya perilaku agresifitas di Indonesia. Oleh karena itu, penelitian ini bertujuan untuk mengidentifikasi variabel-variabel yang memengaruhi perilaku prososial dan melihat kecenderungannya. Data yang dianalisis bersumber dari Survei Pengukuran Tingkat Kebahagiaan (SPTK) 2017 yang dilaksanakan oleh BPS. Sementara itu, analisis yang digunakan yaitu analisis deskriptif dengan tabulasi silang antara perilaku prososial dengan karakteristiknya, dan analisis inferensia dengan regresi logistik biner. Variabel respons yang digunakan yaitu perilaku prososial, sedangkan variabel bebasnya yaitu variabel-variabel kebahagiaan, modal sosial, dan sosiodemografis. Hasil penelitian menunjukkan bahwa variabel-variabel yang berpengaruh terhadap perilaku prososial yaitu kepuasan hidup, perasaan, makna hidup, sikap percaya dan toleransi, usia, dan pendapatan. Selain variabel pendapatan, keenam variabel lain berpengaruh positif terhadap perilaku prososial. Sedangkan variabel pendapatan memiliki pengaruh negatif.
\end{abstract}

Kata kunci: prososial, kebahagiaan, modal sosial, regresi logistik biner

\section{ABSTRACT}

The prosocial behavior of Indonesian population in 2017 was decreased compared to 2016. This decline was followed by an increase in aggressive behavior in Indonesia in 2017. If this is not addressed immediately, it will be one of the triggers for increasing aggressive behavior in Indonesia. Therefore, this study aims to identify the variables that influence prosocial behavior and observe their tendencies. The data source used here is the 2017 Happiness Level Measurement Survey (SPTK) conducted by BPS. Meanwhile, the analysis used is descriptive analysis with cross tabulation between prosocial behavior and the characteristics, and inferential analysis with binary logistic regression. The response variable is prosocial behavior, while the independent variables are happiness, social capital, and sociodemographic variables. The results showed that the variables which influenced prosocial behavior were life satisfaction, feelings, sense of life meaning, trust and tolerance, age, and income. Except the income variable, other variables have a positive affect towards prosocial behavior. While the income variable has a negative affect.

Keywords: prosocial, happiness, social capital, binary logistic regression

\section{PENDAHULUAN}

Manusia disebut sebagai makhluk individual sekaligus makhluk sosial. Manusia disebut sebagai makhluk sosial karena manusia berhubungan secara timbal-balik dengan manusia lain. Dalam memenuhi kebutuhan dan mencapai tujuannya, manusia tidak lepas dari manusia lain dan lingkungan sosialnya. Weinstein dan Ryan (2010) mendefinisikan prososial sebagai berbagai tindakan melindungi dan meningkatkan kesejahteraan orang lain. Oleh karenanya, perilaku prososial menjadi cukup penting dalam kehidupan bermasyarakat. Sayangnya, jika dibandingkan tahun sebelumnya, kecenderungan perilaku prososial baik secara global maupun di Indonesia pada tahun 2017 mengalami penurunan. Kau (2010) menyatakan rendahnya perilaku tolong menolong, berbagi dan bekerjasama antara remaja dengan remaja, orang lain, orang tua maupun masyarakat dapat memperlihatkan fenomena menurunnya perilaku prososial pada remaja. Dilansir dari Charity Aid Foundation (2018) bahwa secara signifikan tahun 2017 lebih sedikit orang di seluruh belahan dunia yang melaporkan menyumbangkan uang untuk amal. Pada tahun 2017, untuk pertama kalinya World Giving Index (WGI) - indeks yang mengukur perilaku prososial masyarakat dunia- Indonesia menduduki peringkat pertama di dunia dengan indeks sebesar 59 persen. Namun, meskipun menduduki peringkat pertama, ternyata WGI Indonesia Indonesia menunjukkan tren kurang bagus. Hal ini terlihat dari Tabel 1 yang mana WGI Indonesia tahun 2014-2017 relatif meningkat, akan tetapi pada tahun 2016-2017 mengalami penurunan. Penurunan ini juga diikuti oleh ketiga variabel pembentuk WGI yaitu partisipasi dalam membantu orang lain, mendonasikan uang, dan menghabiskan waktu dalam kesukarelawanan. 
Tabel 1. Indeks berbagi dan skor partisipasi dalam perilaku berbagi Indonesia tahun 2012-2017.

\begin{tabular}{ccccccccc}
\hline \multirow{2}{*}{ Tahun } & \multicolumn{2}{c}{ Indeks berbagi } & \multicolumn{2}{c}{$\begin{array}{c}\text { Membantu } \\
\text { orang lain }\end{array}$} & \multicolumn{2}{c}{ Mendonasikan uang } & \multicolumn{2}{c}{$\begin{array}{c}\text { Kesukare- } \\
\text { lawanan }\end{array}$} \\
\cline { 2 - 9 } & Skor & Peringkat & Skor & Peringkat & Skor & Peringkat & Skor & Peringkat \\
\hline 2012 & 44 & 17 & 40 & 95 & 63 & 10 & 30 & 22 \\
2013 & 51 & 13 & 48 & 67 & 66 & 10 & 40 & 13 \\
2014 & 46 & 22 & 35 & 123 & 67 & 9 & 38 & 15 \\
2015 & 56 & 7 & 43 & 104 & 75 & 2 & 50 & 3 \\
2016 & 60 & 2 & 47 & 76 & 79 & 2 & 55 & 1 \\
2017 & 59 & 1 & 46 & 97 & 78 & 2 & 53 & 1 \\
\hline
\end{tabular}

Sumber : $C A F$

Rendahnya perilaku prososial dapat memicu meningkatnya risiko perilaku agresif- perilaku yang ditujukan untuk menimbulkan kerugian fisik maupun psikologis kepada orang lain (Obsuth, Eisner, Malti, dan Ribeaud, 2015). Sehingga, dengan menurunnya perilaku prososial ini dapat menimbulkan berbagai masalah, salah satunya yaitu meningkatnya meningkatnya risiko perilaku agresif yang dapat berdampak pada turunnya rasa aman di masyarakat. Hal ini didukung dengan data Global Peace Index (GPI) yang dirilis The Institute for Economics \& Peace (IEP), yang menyatakan bahwa pada tahun 2015-2017 Indonesia mengalami peningkatan GPI yang artinya kedamaian/keamanan Indonesia mengalami penurunan. Bahkan peringkat GPI Indonesia pada tahun 2017 mengalami kemerosotan jika dibandingkan tahun 2016 yaitu dari peringkat 42 menjadi peringkat 52. Kemerosotan ini merupakan yang terbesar di wilayah Asia-Pasifik (The Institute for Economic \& Peace, 2017). Menurunnya kedamaian/keamanan ini diikuti dengan meningkatnya angka kriminalitas di Indonesia, di mana proporsi korban kekerasan yang melaporkan kepada polisi pada tahun 20162017 terjadi peningkatan yang tajam, yaitu dari 18,9 persen menjadi 46,37 persen. Angka pada tahun 2017, merupakan persentase tertinggi yang terjadi dalam 6 tahun terakhir.

Indonesia sebagai bangsa yang kaya akan budaya dan adat istiadat yang memiliki nilai-nilai luhur yang merupakan perwujudan perilaku prososial. Namun, perilaku prososial masyarakat Indonesia seiring berkembangnya zaman menunjukkan adanya kemunduran. Hamidah (2002) menemukan indikasi penurunan perilaku prososial yang terbukti dengan menurunnya kepedulian sosial dan kepekaan terhadap orang lain dan lingkungan di tujuh daerah di Jawa Timur (Lestari \& Partini, 2015). Sejalan dengan Hamidah, Hasil survei yang dilakukan Cahyaningroom (2015) pada tanggal 20 Mei 2014 di SMK Taman Siswa Sukoharjo menunjukkan bahwa dari 30 siswa yang disurvei terdapat gejala penurunan perilaku prososial. Selain itu, Badan Amil Zakat Nasional (2018) menunjukkan persentase pertumbuhan jumlah zakat, infak, dan sedekah (ZIS) yang terhimpun melalui Baznas pada tahun 2017 lebih rendah dibandingkan persentase pertumbuhan ZIS tahun 2016. Artinya, jika dilihat dari penghimpunan ZIS yang merupakan salah satu bentuk perilaku berdonasi-merupakan bentuk perilaku prososial - terdapat penurunan pertumbuhan perilaku prososial di Indonesia pada tahun 2017.

Di era modernisasi dan globalisasi ini perilaku prososial masyarakat Indonesia sudah mengalami pergeseran nilai-nilai kolektif dan kebersamaannya. Seperti yang ditemukan Suyatni (2017)bahwa masyarakat Jelantik sudah mulai kurang memikirkan kepentingan bersama. Masyarakat kurang antusian dalam mengikuti kegiatan yang ada. Sejalan dengan Suyatni (2017), BPS menunjukkan tren indeks modal sosial Indonesia tahun 2012-2017 mengalami penurunan. Di mana modal sosial merupakan salah satu kunci individu dalam perilaku beramal dan kesukarelawanan (Bekkers dalam Wang \& Graddy, 2008). Sehingga, jika hal ini dibiarkan, semakin lama perilaku prososial masyarakat Indonesia akan turut mengalami penurunan. Banyak penelitian yang telah mengungkapkan bagaimana suasana hati yang positif dapat meningkatkan respons prososial (Bartlett \& DeSteno, 2006). Berdasarkan data BPS, tingkat kebahagiaan Indonesia tahun 2017 lebih tinggi dibandingkan tahun 2014. Namun, Sustainable Development Solutions Network (SDSN) menunjukkan fakta yang bertolak belakang. Di mana berdasarkan data SDSN, terjadi penurunan tingkat kebahagiaan Indonesia pada periode 2014-2016 ke periode 2015-2017, bahkan penurunan ini merupakan yang paling tajam sejak periode 2010. Persentase pertumbuhan jumlah ZIS dan donatur di Indonesia pada tahun 2017 mengalami penurunan dibandingkan tahun 2016 (Baznas, 2018). Padahal jika dilihat, laju pertumbuhan PDB menurut pengeluaran Indonesia tahun 2017 lebih tinggi dibandingkan tahun 2016. Fakta ini berlawanan dengan temuan Bekkers dan De Graaf (2005) di mana secara signifikan pendapatan berpengaruh positif ter terhadap perilaku prososial yang berupa donor darah, kesukarelawanan, dan berbagi.

Penelitian terkait topik prososial di Indonesia selama ini sebagian besar berfokus pada instansi atau kelompok masyarakat tertentu. Penelitian perilaku prososial pada level kabupaten/kota bahkan level nasional 
masih belum tersedia. Muharram (2018) meneliti perilaku prososial peserta Aksi Bela Islam 212, hasil temuannya menunjukkan bahwa terdapat 3 variabel yang memengaruhi perilaku prososial, yaitu religious altruism, religious enrichment, dan empati. Ketiga variabel tersebut memberikan pengaruh positif terhadap perilaku prososial. Penelitian lain terkait perilaku prososial dilakukan oleh Brown dan Ferris (2007) dan Wang dan Graddy (2008). Penelitian yang dilakukan oleh Brown dan Ferris (2007) menunjukkan bahwa variabel modal sosial dan modal manusia berperan terhadap religious giving, secular giving, dan kesukarelawanan bentuk perilaku prososial. Adapun penelitian Wang dan Graddy (2008) menghasilkan temuan bahwa variabel kebahagiaan berpengaruh signifikan terhadap religious giving. Sementara itu, modal sosial yang berpengaruh secara signifikan terhadap religious giving dan secular giving yaitu variabel kepercayaan sosial, bridging network, keterlibatan masyarakat, dan frekuensi volunteering.

Perilaku prososial yang rendah dapat menjadi salah satu pemicu agresifitas. Sehingga menurunnya perilaku prososial ini menjadi hal yang penting untuk diselesaikan. Berdasarkan uraian permasalahan diatas, terdapat tiga tujuan penelitian yang mendasari penelitian ini. Pertama, penelitian ini bertujuan untuk mendapatkan gambaran umum perilaku prososial di Indonesia tahun 2017. Selanjutnya yaitu mengidentifikasi variabel yang memengaruhi perilaku prososial di Indonesia tahun 2017. Dan tujuan terakhir yaitu menganalisis kecenderungan perilaku prososial di Indonesia tahun 2017.

\section{METODE}

Perilaku diartikan sebagai respons atau reaksi seseorang terhadap setimulus dari luar (Skiner dalam Suharyat, 2009). Walgito (2004) mendefinisikan perilaku dengan pendekatan formulasi $B=f(E, O)$ dengan $B$ $=$ behavior atau perilaku; $\mathrm{f}=$ function atau fungsi; $\mathrm{E}=$ environment atau lingkungan; dan $\mathrm{O}=$ organism atau organisme. Sehingga berdasarkan formulasi tersebut, lingkungan dan organsim mempengaruhi perilaku. Perilaku menurut Triwibowo dalam Arthini (2019) dibagi menjadi tiga domain karena perilaku manusia mempunyai ruang lingkup yang sangat luas. Ketiga domain tersebut yaitu: pengetahuan, sikap, tindakan atau praktik. Sedangkan istilah "sosial" oleh Ritzer (1980) dalam Wirawan (2015) dikenalkan tiga paradigma, yaitu: (1) paradigma fakta sosial, (2) paradigma definisi sosial, dan (3) paradigma perilaku sosial. Dalam paradigma fakta sosial, manusia dipandang sebagai masyarakat dengan sudut pandang struktur yang makro (Wirawan, 2015). Sedangkan dalam paradigma definisi sosial berangkat dari proses berpikir manusia itu sendiri sebagai individu. Individu sebagai pelaku tindakan di dalam bertindak atau berinteraksi berada di bawah pengaruh struktur sosial dan pranata-pranata yang berlaku di masyarakat. Sementara itu, paradigma perilaku sosial memandang perilaku sosial dapat dipelajari dan diamati secara empiris. Namun, apa yang ada di balik perilaku tersebut berada di luar amatan paradigma ini.

Perilaku prososial didefinisikan oleh Eisenberg et al. (2015) sebagai perilaku sosial yang menguntungkan orang lain (Obsuth, Eisner, Malti, dan Ribeaud, 2015). Beberapa peneliti mendefinisikan perilaku prososial dengan perilaku yang ditujukan untuk meningkatkan atau memelihara kesejahteraan orang lain (Piliavin et al. dalam Smith, 2019; Weinstein dan Ryan, 2010; Bierhoff, 2002). Namun, Bierhoff (2002) memberikan pandangan yang sedikit berbeda dengan sebelum-sebelumnya. Istilah "membantu" merupakan istilah yang paling umum, termasuk semua bentuk dukungan interpersonal. Sedangkan perilaku prososial didefinisikan lebih sempit dari "membantu", aksi ini ini ditujukan untuk meningkatkan keadaan penerima bantuan dengan tidak dimotivasi oleh tanggung jawab professional. Istilah "altruism" merupakan perilaku prososial yang motivasi penolongnya ditandai dengan pembilan perspektid dan empati. Aspek perilaku prososial menurut Dovidio, Piliavin, Schroeder, dan Penner (2017) dibagi menjadi 3 sub kategori, yaitu membantu, altruism, dan kerja sama. Schroeder dan Graziano (2015), selain ketiga sub kategori tersebut menambahkan domain kesukarelawanan (volunteering). Sedangkan Sampson dalam Jannah (2008) menyebutkan aspek perilaku prososial yaitu berdonasi (donating), kerja sama (cooperating), memberi (giving), peduli (caring), memfasilitasi kesejahteraan orang lain (facilitating the wellbeing of the other), membantu (helping), dan berbagi (sharing).

Jejaring sosial merupakan salah satu faktor yang memengaruhi kemunculan pemberian amal (Putnam dalam Wang dan Graddy, 2008). Basti (2007) mengemukakan bahwa faktor yang memengaruhi perilaku prososial terdiri dari faktor internal dan faktor eksternal. Faktor internal terdiri dari karakteristik kepribadian, suasana hati, religiusitas pertimbangan untung rugi, kemampuan yang dimiliki, keuntungan pribadi, nilai dan norma-norma pribadi, empati dan jenis kelamin. Sedangkan faktor eksternal mencakup budaya, keluarga, karakteristik orang yang membutuhkan pertolongan. Sementara itu, faktor yang mendasari perilaku prososial jika dilihat dari tingkat analisisnya terbagi menjadi tiga tingkat yaitu: (1) level meso, (2) level mikro, dan (3) level makro (Penner, Dovidio, Piliavin, \& Schroeder, 2005). Pada level meso meneliti perilaku membantu pada tingkat interpersonal. Pada level ini terdapat pendekatan terhadap alasan membantu dengan tiga jenis 
mekanisme, yaitu : pembelajaran, standar sosial dan pribadi, gairah dan afeksi. Tingkatan yang kedua yaitu level mikro. Pada level ini, alasan mengapa seseorang melakukan aksi prososial dijelaskan dengan teori evolusi, biologis dan genetika, dan kepribadian. Dalam teori evolusi, disebutkan bahwa dalam memenuhi tujuan kelangsungan hidup pada individu dan diturunkan kepada generasi selanjutnya terdapat tiga proses yaitu kesesuaian inklusif dan seleksi kerabat, altruisme timbal balik, dan seleksi kelompok. Tingkatan terakhir yang mendasari perilaku prososial yaitu level makro. Pada tingkatan ini, dibagi menjadi 2 pembahasan, dimana bagian pertama membahas perilaku prososial yang dilakukan oleh individu dalam konteks organisasi dengan fokus utamanya yaitu perilaku kesukarelaan dan hubungan. Dilanjutkan dengan bagian keduanya mengeksplorasi dinamika kerja sama. Selain faktor-faktor yang telah diuraikan diatas, prososial juga dipengaruhi oleh kepercayaan sosial (Putnam, 2004).

Berdasarkan teori-teori yang telah diuraikan tersebut, maka terbentuklah model konseptual seperti yang ditunjukkan pada Gambar 1. Kerangka pikir ini diadopsi dari kerangka pikir Wang dan Graddy (2008) dengan disesuaikan dengan ketersediaan data yang ada. Anak panah tersebut menunjukkan adanya dugaan pengaruh variabel kepuasan hidup, perasaan, kebermaknaan hidup, sikap percaya dan toleransi, jejaring, umur, dan tingkat pendapatan terhadap perilaku prososial di Indonesia pada tahun 2017.

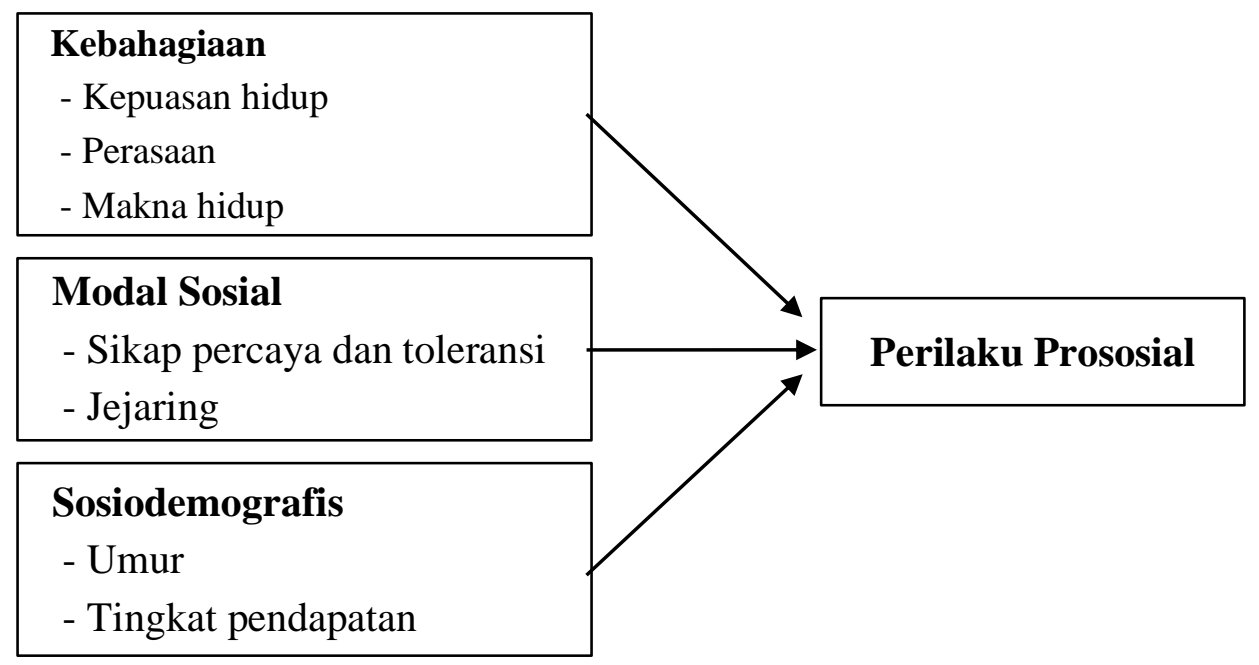

Gambar 1. Kerangka Pikir Penelitian.

Guna menjawab tujuan penelitian yang pertama, dilakukan analisis deskriptif dengan menyajikan tabulasi silang antara ketujuh variabel bebas dan variabel klasifikasi wilayah, status kawin, jenis kelamin, dan tingkat pendidikan dengan perilaku prososial. Sedangkan untuk menjawab tujuan penelitian yang kedua dan ketiga menggunakan analisis inferensia dengan permodelan perilaku prososial terhadap ketujuh variabel bebas dengan metode analisis regresi logistik biner. Variabel perilaku prososial, dan sikap percaya dan toleransi diperoleh dari rata-rata sederhana dari beberapa indikator yang kemudian diubah menjadi biner berdasarkan nilai cut off-nya yaitu 0,5 . Sedangkan, variabel kepuasan hidup, perasaan, dan makna hidup dihitung dengan menggunakan penimbang untuk masing-masing indikator kemudian diubah menjadi biner dengan nilai median sebagai cut off-nya. Adapun indikator-indikator, dimensi, dan sumber data yang digunakan untuk membentuk variabel-variabel dalam penelitian ini diuraikan pada Lampiran 1-3. Model regresi logistik biner dibentuk sebagai berikut:

$$
\begin{aligned}
& \pi(x)=\frac{\exp \left(\beta_{0}+\beta_{1} x_{1}+\beta_{2} x_{2}+\ldots+\beta_{7.1} x_{7.1}+\ldots+\beta_{7.4} x_{7.4}\right)}{1+\exp \left(\beta_{0}+\beta_{1} x_{1}+\beta_{2} x_{2}+\ldots+\beta_{7.1} x_{7.1}+\ldots+\beta_{7.4} x_{7.4}\right)} \\
& \text { dengan } \\
& \pi(x) \quad=\text { peluang untuk perilaku prososial }(\mathrm{Y}=1) \\
& \beta_{0} \quad=\text { koefisien intersep } \\
& \beta_{1} \ldots \beta_{7.4}=\text { koefisein regresi/slope }
\end{aligned}
$$

Selanjutnya dilakukan beberapa tahap pengujian pada model, yaitu uji simultan, uji parsial, dan uji kesesuaian model (goodness of fit). Uji simultan dilakukan guna mengetahui apakah variabel di dalam model secara bersama-sama berpengaruh secara signifikan terhadap variabel dependen. Uji selanjutnya yaitu uji parsial, uji ini dilakukan untuk mengidentifikasi variabel bebas mana yang secara signifikan berpengaruh terhadap variabel terikat. Pengujian yang terakhir yaitu uji keseseuaian model untuk mengetahui apakah model yang terbentuk sudah sesuai atau tidak. Setelah selesai dengan ketiga uji tersebut, maka dilakukan interpretasi odds ratio untuk mengetahui kecenderungan masing-masing variabel. 


\section{Data dan Sumber Data}

Penelitian ini dicakup seluruh provinsi yang ada di Indonesia. Variabel respons yang digunakan dalam penelitian ini yaitu perilaku prososial yang terdiri dari kategori kurang prososial dan prososial. Sementara itu. Variabel bebas yang dianalisis yaitu tingkat kebahagiaan, modal sosial, dan sosiodemografis seperti yang terlihat pada Gambar 1. Selain ketujuh variabel diatas, terdapat beberapa variabel lain yang dianalisis secara deskriptif untuk menjawab tujuan penelitian pertama. Variabel-variabel tersebut yaitu status kawin, klasifikasi wilayah, jenis kelamin, dan tingkat pendidikan. Data yang dgunakan dalam penelitian ini bersumber dari Survei Pengukuran Tingkat Kebahagiaan (SPTK) tahun 2017 yang dilaksanakan oleh Badan Pusat Statistik (BPS). Pelaksanaan pengumpulan data SPTK 2017 dilakukan dalam kurun waktu tanggal 5-30 April 2017 yang dilaksanakan pada 34 provinsi dengan cakupan 487 kabupaten/kota yang ada di Indonesia. Pada penelitian ini, dicakup keseluruhan wilayah tersebut. Setiap rumah tangga yang menjadi sampel, responden yang dipilih sebagai perwakilan rumah tangga tersebut adalah kepala rumah tangga (KRT) atau pasangan KRT (isteri/suami). Sehingga penduduk yang dimaksud dalam survei dan penelitian ini adalah KRT atau pasangannya.

SPTK 2017 dilaksanakan secara serentak di 34 provinsi di seluruh Indonesia dengan total sampel yang dicakup sebanyak 75.000 rumah tangga yang tersebar di 487 kabupaten/kota. Unit analisis dari survei ini adalah rumah tangga yang dipilih secara acak (random). Sedangkan metode yang digunakan dalam penarikan sampel (sampling method) survey ini yaitu two stage one phase sampling.

\section{HASIL DAN PEMBAHASAN}

Perilaku prososial masyarakat Indonesia secara nasional masih tergolong menengah, hal ini ditunjukkan dari 72317 orang yang menjadi sampel persentase masyarakat yang tergolong perilaku prososial hanya sebesar 43,43 persen. Sedangkan sisanya yaitu 56,57 persen tergolong kurang prososial. Dari Gambar 2 juga terlihat bahwa lebih dari setengah jumlah provinsi yang ada di Indonesia, yaitu 21 provinsi memiliki persentase masyarakat yang tergolong berperilaku prososial di bawah persentase nasional. Adapun, tiga provinsi dengan persentase perilaku prososial terendah terjadi di Bangka Belitung (23,95 persen), DKI Jakarta (26,95 persen), dan Sulawesi Selatan (32,14 persen). Sedangkan provinsi dengan persentase perilaku prososial tertinggi terjadi di D.I. Yogyakarta (68,12 persen) kemudian disusul oleh Sulawesi Utara $(64,45$ persen) dan Nusa Tenggara Timur (59,55 persen). Provinsi Bangka Belitung dan DKI Jakarta yang termasuk dalam lima provinsi dengan pengeluaran per kapita tertinggi di Indonesia justru memiliki perilaku prososial terendah di Indonesia. Sementara itu, provinsi Nusa Tenggara Timur yang termasuk provinsi dengan pengeluaran per kapita terendah kedua di Indonesia justru memiliki perilaku prososial tertinggi ketiga di Indonesia.

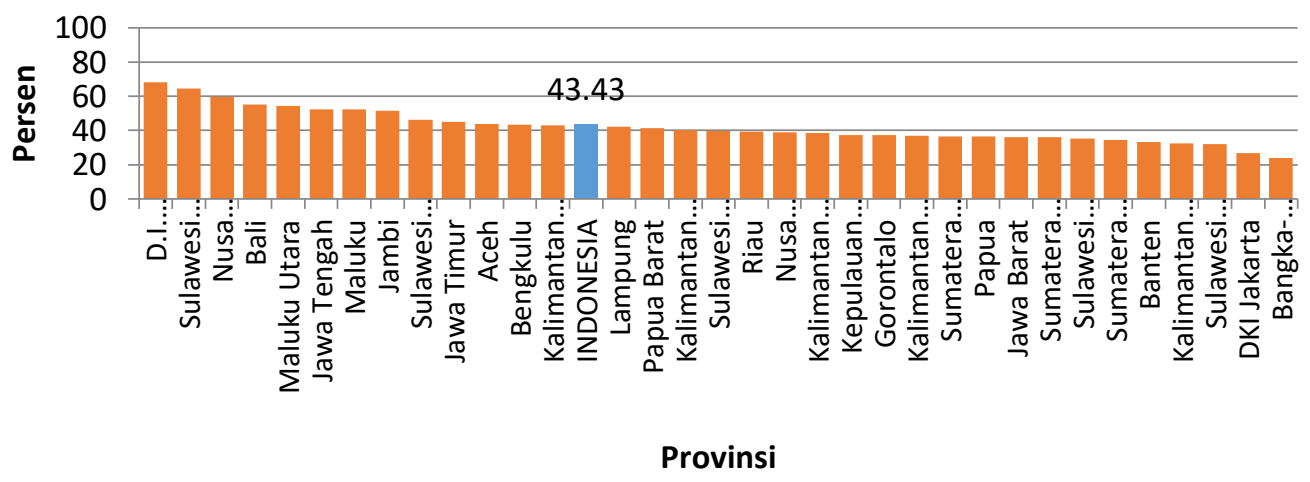

Sumber: SPTK 2017, diolah

Gambar 2. Persentase Penduduk Indonesia yang Tergolong Prososial Menurut Provinsi, 2017.

Adapun perilaku prososial penduduk Indonesia pada tahun 2017, jika dilihat pada Tabel 2 menunjukkan adanya indikasi kecenderungan karakteristik tertentu dalam melakukan perilaku prososial. Selain itu, juga sudah dilakukan pengujian Chi-Square yang bertujuan untuk melihat adanya hubungan antara perilaku prososial dengan karakteristik-karakterisriknya. Hasilnya terlihat pada Tabel 2 bahwa semua karakteristik latar belakangnya memiliki $p$-value $=0,000$ yang berarti bahwa seluruh karakteristik terdapat hubungan dengan perilaku prososial. Berdasarkan klasifikasi wilayah tempat tinggalnya, perilaku prososial sebagian besar muncul di daerah perdesaan. Sebanyak 45,60 persen penduduk yang tinggal di pedesaan terkategorikan berperilaku prososial, sedangkan penduduk yang tinggal di perkotaan yang tergolong berperilaku prososial 
sebesar 38,08 persen. Sementara itu, berdasarkan status kawinnya, persentase penduduk berperilaku prososial tertinggi terjadi pada penduduk berstatus kawin. Sedangkan, untuk persentase perilaku prososial terendah terjadi pada penduduk berstatus belum kawin, yang mana hanya 21,80 persen penduduk yang belum kawin yang tergolong berperilaku prososial. Selain itu, perilaku prososial berdasarkan kelompok usianya memiliki pola U terbalik dengan puncaknya di kelompok usia 41-64 tahun. Penduduk yang berjenis kelamin laki-laki memiliki persentase yang tergolong perilaku prososial lebih banyak dibandingkan penduduk yang berjenis kelamin perempuan. Karakteristik selanjutnya yaitu pendidikan dan pendapatan menunjukkan indikasi kecenderungan positif. Artinya, persentase perilaku prososial semakin tinggi seiring dengan peningkatan pendidikan atau pendapatan. Hal serupa juga terjadi pada variabel-variabel kebahagiaan -kepuasan hidup, perasaan, makna hidup - dan modal sosial -sikap percaya dan toleransi, dan jejaring, dimana terdapat indikasi bahwa penduduk yang tergolong puas dengan aspek kehidupan, merasa senang, hidupnya bermakna, percaya dan toleran terhadap lingkungan, dan berjejaring memiliki persentase berperilaku prososial yang lebih tinggi dibandingkan penduduk yang tergolong kurang dalam variabel kebahagiaan dan modal sosial.

Tabel 2. Tabulasi silang dan uji Chi-Square karakteristik penduduk dengan perilaku prososial

\begin{tabular}{|c|c|c|c|c|c|}
\hline \multirow{2}{*}{ No } & \multirow{2}{*}{ Variabel } & \multirow{2}{*}{ Kategori } & \multicolumn{2}{|c|}{ Perilaku Prosial } & \multirow{2}{*}{ Total } \\
\hline & & & Kurang Prososial & Prososial & \\
\hline \multirow{2}{*}{1} & \multirow{3}{*}{$\begin{array}{c}\text { Klasifikasi Wilayah } \\
(p \text {-value }=0,000)\end{array}$} & Perkotaan & $61.92 \%$ & $38.08 \%$ & $100 \%$ \\
\hline & & Perdesaan & $54.40 \%$ & $45.60 \%$ & $100 \%$ \\
\hline \multirow{4}{*}{2} & & Belum Kawin & $78.20 \%$ & $21.80 \%$ & $100 \%$ \\
\hline & \multirow{4}{*}{$\begin{array}{c}\text { Status Kawin } \\
(p \text {-value }=0,000)\end{array}$} & Kawin & $54.80 \%$ & $45.20 \%$ & $100 \%$ \\
\hline & & Cerai Hidup & $68.60 \%$ & $31.40 \%$ & $100 \%$ \\
\hline & & Cerai Mati & $68.70 \%$ & $31.30 \%$ & $100 \%$ \\
\hline \multirow{4}{*}{3} & & $<=24 \operatorname{tahun}(r e f)$ & $76.60 \%$ & $23.40 \%$ & $100 \%$ \\
\hline & \multirow{3}{*}{$\begin{array}{c}\text { Usia } \\
(p \text {-value }=0,000)\end{array}$} & $25-40$ tahun & $60.60 \%$ & $39.40 \%$ & $100 \%$ \\
\hline & & 41-64 tahun & $52.90 \%$ & $47.10 \%$ & $100 \%$ \\
\hline & & $>=65$ tahun & $65.60 \%$ & $34.40 \%$ & $100 \%$ \\
\hline \multirow{2}{*}{4} & \multirow{2}{*}{$\begin{array}{c}\text { Jenis Kelamin } \\
(p \text {-value }=0,000)\end{array}$} & Laki-laki & $50.50 \%$ & $49.50 \%$ & $100 \%$ \\
\hline & & Perempuan & $64.30 \%$ & $35.70 \%$ & $100 \%$ \\
\hline \multirow{3}{*}{5} & \multirow{3}{*}{$\begin{array}{c}\text { Pendidikan } \\
(p \text {-value }=0,000)\end{array}$} & Rendah $(<=$ SD sederajat $)(r e f)$ & $59.60 \%$ & $40.40 \%$ & $100 \%$ \\
\hline & & Menengah (SMP-SMA sederajat) & $56.70 \%$ & $43.30 \%$ & $100 \%$ \\
\hline & & Tinggi(Diploma/sarjana) & $51.50 \%$ & $48.50 \%$ & $100 \%$ \\
\hline \multirow{5}{*}{6} & \multirow{5}{*}{$\begin{array}{c}\text { Pendapatan } \\
(p-\text { value }=0,000)\end{array}$} & Sangat Rendah & $60.80 \%$ & $39.20 \%$ & $100 \%$ \\
\hline & & Rendah & $58.30 \%$ & $41.70 \%$ & $100 \%$ \\
\hline & & Menengah & $55.50 \%$ & $44.50 \%$ & $100 \%$ \\
\hline & & Tinggi & $54.70 \%$ & $45.30 \%$ & $100 \%$ \\
\hline & & Sangat tinggi $(r e f)$ & $51.60 \%$ & $48.40 \%$ & $100 \%$ \\
\hline \multirow{2}{*}{7} & \multirow{2}{*}{$\begin{array}{l}\text { Kepuasan Hidup } \\
(p \text {-value }=0,000)\end{array}$} & Puas & $53.40 \%$ & $46.60 \%$ & $100 \%$ \\
\hline & & Kurang Puas $(r e f)$ & $62.20 \%$ & $37.80 \%$ & $100 \%$ \\
\hline \multirow{2}{*}{8} & \multirow{2}{*}{$\begin{array}{c}\text { Perasaan } \\
(p \text {-value }=0,000)\end{array}$} & Senang & $53.80 \%$ & $46.20 \%$ & $100 \%$ \\
\hline & & Kurang Senang(ref) & $60.60 \%$ & $39.40 \%$ & $100 \%$ \\
\hline \multirow{2}{*}{9} & \multirow{2}{*}{$\begin{array}{c}\text { Makna Hidup } \\
(p \text {-value }=0,000)\end{array}$} & Bermakna & $52.50 \%$ & $47.50 \%$ & $100 \%$ \\
\hline & & Kurang Bermakna $(r e f)$ & $64.50 \%$ & $35.50 \%$ & $100 \%$ \\
\hline
\end{tabular}

Tabel 3. Tabulasi silang dan uji Chi-Square karakteristik penduduk dengan perilaku prososial (lanjutan)

\begin{tabular}{|c|c|c|c|c|c|}
\hline \multirow{2}{*}{ No } & \multirow{2}{*}{ Variabel } & \multirow{2}{*}{ Kategori } & \multicolumn{2}{|c|}{ Perilaku Prosial } & \multirow{2}{*}{ Total } \\
\hline & & & Kurang Prososial & Prososial & \\
\hline \multirow{2}{*}{10} & Sikap Percaya dan & Percaya dan Toleran & $56.00 \%$ & $44.00 \%$ & $100 \%$ \\
\hline & $\begin{array}{c}\text { Toleransi } \\
(p \text {-value }=0,000)\end{array}$ & Kurang Percaya dan Toleran $(r e f)$ & $64.30 \%$ & $35.70 \%$ & $100 \%$ \\
\hline \multirow{2}{*}{11} & Jejaring & Berjejaring & $42.30 \%$ & $57.70 \%$ & $100 \%$ \\
\hline & $(p$-value $=0,000)$ & Kurang Berjejaring $(r e f)$ & $65.30 \%$ & $34.70 \%$ & $100 \%$ \\
\hline
\end{tabular}

Sumber: SPTK 2017, diolah

Keterangan : kategori bertanda (ref) merupakan kategori referensi. 
Setelah dilakukan analisis deskriptif, maka selanjutnya melakukan pemodelan perilaku prososial dengan tujuh variabel yang telah diuraikan pada kerangka pikir. Pemodelan ini ditujukan untuk mengidentifikasi pengaruh dari ketujuh variabel tersebut terhadap perilaku prososial dengan menggunakan metode regresi logistik biner. Pengujian simultan telah dilakukan, dan diperoleh $p$-value sebesar 0,000 , sehingga dapat disimpulkan bahwa dengan tingkat signifikansi 5 persen minimal terdapat satu variabel bebas yang memengaruhi perilaku prososoial di Indonesia tahun 2017. Selanjutnya, hasil dari analisis regresi logistik biner disajikan pada Tabel 3. Adapun, model yang terbentuk sebagai berikut

$$
\begin{aligned}
\hat{\pi}(x)= & \exp \exp \left(-1,965+0,160 X_{1}+0,085 X_{2}+0,331 X_{3}+0,246 X_{4}+0,870 X_{5}-0,739 X_{6.1}+\right. \\
& \left.1,045 X_{6.2}+0,629 X_{6.3}-0,037 X_{7.1}-0,012 X_{7.2}-0,093 X_{7.3}-0,079 X_{7.4}\right) /[1+ \\
& \left.\exp \left(-1,965+\cdots+0,079 X_{7.4}\right)\right]
\end{aligned}
$$

Dari ketujuh variabel yang dimasukkan ke dalam model, terlihat bahwa ketujuh variabel tersebut signifikan pada signifikansi 5 persen. Hal ini berarti bahwa semua variabel yang dimasukkan ke dalam model berpengaruh terhadap perilaku prososial. Setelah itu, uji kesesuaian model dilakukan untuk mengetahui apakah model yang terbentuk sudah sesuai atau belum dalam menjelaskan perilaku prososial di Indonesia. Berdasarkan hasil pengujian, diperoleh $p$-value sebesar 0,154 . Hal ini berarti dengan signifikansi 5 persen dapat disimpulkan model yang ada mampu menjelaskan data yang digunakan. Dengan kata lain, tidak terdapat perbedaan antara hasil prediksi dan amatan dari model.

Tabel 4. Ringkasan output dari analisis regresi logisitk biner

\begin{tabular}{lccccccc}
\hline \multicolumn{1}{c}{ Variabel } & Notasi & B & S.E. & Wald & df & $p$-value & $\operatorname{Exp(B)~}$ \\
\hline Kepuasanhidup(puas) & $\mathrm{X}_{1}$ & 0,160 & 0,018 & 79,450 & 1 & $0,000^{*}$ & 1,174 \\
Perasaan(senang) & $\mathrm{X}_{2}$ & 0,085 & 0,017 & 25,203 & 1 & $0,000^{*}$ & 1,088 \\
Maknahidup(bermakna) & $\mathrm{X}_{3}$ & 0,331 & 0,018 & 334,517 & 1 & $0,000^{*}$ & 1,392 \\
Percayadantoleransi(percaya & $\mathrm{X}_{4}$ & 0,246 & 0,020 & 145,217 & 1 & $0,000^{*}$ & 1,279 \\
dan toleran) & $\mathrm{X}_{5}$ & 0,870 & 0,016 & 2799,815 & 1 & $0,000^{*}$ & 2,388 \\
Jejaring(berjejaring) & & & & & & & \\
Usia & $\mathrm{X}_{6.1}$ & 0,739 & 0,052 & 199,638 & 1 & $0,000^{*}$ & 2,093 \\
Usia(25-40 tahun) & $\mathrm{X}_{6.2}$ & 1,045 & 0,052 & 408,910 & 1 & $0,000^{*}$ & 2,842 \\
Usia(41-64 tahun) & $\mathrm{X}_{6.3}$ & 0,629 & 0,056 & 124,672 & 1 & $0,000^{*}$ & 1,876 \\
Usia( $\geq 65$ tahun) & & & & & & & \\
Pendapatan & $\mathrm{X}_{7.1}$ & $-0,037$ & 0,020 & 3,363 & 1 & 0,067 & 0,963 \\
Pendapatan(rendah) & $\mathrm{X}_{7.2}$ & $-0,012$ & 0,023 & 0,281 & 1 & 0,596 & 0,988 \\
Pendapatan(menengah) & $\mathrm{X}_{7.3}$ & $-0,093$ & 0,028 & 10,692 & 1 & $0,001^{*}$ & 0,912 \\
Pendapatan(tinggi) & $\mathrm{X}_{7.4}$ & $-0,079$ & 0,031 & 6,624 & 1 & $0,010^{*}$ & 0,924 \\
Pendapatan(sangat tinggi) & & $-1,965$ & 0,055 & 1280,582 & 1 & $0,000^{*}$ & 0,140 \\
Konstanta & & & & & &
\end{tabular}

Sumber: SPTK 2017, diolah

Keterangan : *: signifikan pada $\alpha=0,05$

Berdasarkan Tabel 3 dapat diketahui rasio kecenderungan dari masing-masing variabel yang berpengaruh terhadap perilaku prososial secara signifikan. Rasio kecenderungan ditampilkan pada kolom Exp(B) yang diperoleh dari eksponensial pendugaan parameternya.

Variabel kepuasan hidup memiliki koefisien 0,160 dengan rasio kecenderungannya 1,174. Hal ini dapat diartikan bahwa penduduk yang tergolong puas dengan kehidupan memiliki kecenderungan 1,174 kali lebih besar untuk berperilaku prososial daripada penduduk yang kurang puas. Sehingga dapat disimpulkan bahwa perilaku prososial lebih tinggi terjadi pada penduduk yang tergolong puas pada hidupnya. Hasil ini sejalan dengan penelitian Martin dan Huebner dalam Martin, Huebner, dan Valois (2008) yang menunjukkan bahwa remaja dengan kepuasan hidup yang rendah mengalami lebih sedikit interaksi prososial.

Variabel perasaan memiliki koefisien 0,085 dengan rasio kecenderungan 1,088. Hal ini berarti penduduk yang tergolong senang memiliki kecenderungan untuk berperilaku prososial 1,088 kali lebih besar dibandingkan penduduk yang kurang senang. Dengan kata lain, perilaku prososial lebih besar terjadi pada penduduk yang tergolong senang. Sejalan dengan hal ini, para peneliti (Laknin, Van de Vondervoort, \& Hamlin, 2018; Cuadrado, Tabernero, dan Steinel, 2015) menyatakan bahwa suasana hati yang positif mampu meningkatkan respons prososial. Hal ini dikarenakan perasaan merupakan salah satu fundamental dalam membantu (Penner, Dovidio, Piliavin, dan Schroeder, 2005). 
Variabel makna hidup memiliki koefisien 0,331 dan rasio kecenderungan 1,392. Hal ini berarti penduduk yang tergolong hidupnya bermakna memiliki kecenderungan untuk berperilaku prososial 1,392 kali lebih besar dibandingkan penduduk yang tergolong kurang bermakna. Sehingga dapat disimpulkan bahwa penduduk yang hidupnya bermakna lebih prososial dibandingkan yang hidupnya kurang bermakna. Hal ini sejalan dengan para ahli teori yang mengungkapkan bahwa kehidupan yang bermakna cenderung lebih bertanggung jawab secara sosial dan berperilaku prososial (Ryan et al. dalam Yang et al., 2016).

Variabel percaya dan toleransi memiliki koefisien 0,246 dengan rasio kecenderungannya 1,279. Hal ini menunjukkan bahwa penduduk yang tergolong percaya dan toleran memiliki kecenderungan untuk berperilaku prososial 1,279 kali lebih besar dibandingkan penduduk yang kurang percaya dan toleran. Sehingga dapat disimpulkan bahwa penduduk yang percaya dan toleran cenderung lebih prososial dibandingkan penduduk yang kurang percaya dan toleran. Sejalan dengan hal ini, para peneliti (Putnam 2004; Bekkers 2005; Cuadrado, Tabernero, dan Steinel 2015) menyatakan bahwa orang-orang yang memiliki rasa percaya satu sama lain ataupun percaya terhadap lingkungan sekitar cenderung untuk menunjukkan perilaku prososial.

Variabel jejaring memiliki koefisien 0,870 dengan rasio kecenderungan 2,388. Hal ini menunjukkan bahwa penduduk yang tergolong berjejaring memiliki kecenderungan untuk berperilaku prososial 2,388 kali lebih besar dibandingkan penduduk yang kurang berjejaring. Angka ini merupakan odds ratio terbesar kedua dalam penelitian ini. Putnam (2004) menyatakan bahwa jejaring sosial menjadi sarana untuk mendorong perhatian pada kesejahteraan orang lain. Sejalan dengan hasil penelitian ini, Brown dan Ferris (2007) menemukan bahwa jejaring sosial merupakan salah satu faktor yang penting dalam perilaku prososial.

Variabel usia terdiri dari 4 kategori. Kategori dengan koefisien tertinggi yaitu usia 41-64 tahun dengan rasio kecenderungan 1,045. Artinya, orang dengan usia pada rentang 41-64 tahun cenderung berperilaku prososial 2,842 kali lebih besar dibandingkan orang dengan usia 24 tahun ke bawah. Kategori usia ini merupakan kelompok usia dengan kecenderungan perilaku prososial tertinggi dibandingkan kelompok usia yang lain. Adapun kategori usia 65 tahun ke atas memiliki koefisien 0,629 dan kecendurungan 1,876. Artinya kelompok usia 65 tahun ke atas cenderung untuk berperilaku prososial 1,876 lebih besar dibandingkan kelompok usia 24 tahun ke bawah. Kelompok usia ini memiliki kecenderungan untuk berperilaku prososial terendah dibandingkan kelompok usia yang lain. Hal ini sejalan dengan penelitian Wang dan Graddy (2008) yang menemukan bahwa orang yang lebih tua berkontribusi lebih banyak dalam beramal dibandingkan orang yang lebih muda. Hal ini bisa jadi dikarenakan orang yang lebih tua lebih memiliki aset atau kekayaan, pengalaman dan paparan untuk berperilaku prososial.

Variabel pendapatan terdiri lima kategori, yaitu pendapatan sangat rendah sampai pendapatan sangat tinggi. Kategori referensi yang digunakan yaitu kategori pendapatan sangat rendah. Dari kelima kategori tersebut, kategori pendapatan tinggi memiliki koefisien dan rasio kecenderungan terendah yaitu $-0,093$ dan 0,912. Artinya, penduduk dengan pendapatan tinggi cenderung untuk berperilaku prososial 0,912 kali lebih kecil dibandingkan dengan penduduk dengan pendapatan sangat rendah. Adapun, kategori dengan koefisien dan rasio kecenderungan tertinggi yaitu kategori pendapatan menengah dengan koefisien $-0,012$ dan rasio kecenderungan 0,988. Artinya, penduduk dengan pendapatan menengah cenderung untuk berperilaku prososial 0,988 kali lebih kecil dibandingkan penduduk pendapatan yang sangat rendah. Hasil ini bertolak belakang dengan Wang dan Graddy (2008) yang menemukan bahwa perilaku prososial meningkat seiring dengan bertambahnya pendapatan. Independent Sector dalam Piff, et al. (2010) yang menemukan bahwa individu dengan pendapatan rendah secara proposional lebih banyak berdonasi amal dibandingkan dengan individu berpendapatan lebih tinggi. Sebagaimana penjelasan Piff, et al. (2010) bahwa individu kelas bawah bertindak lebih prososial karena meningkatnya orientasi pada kebutuhan orang lain. Namun, jika kita lihat angka-angka tesebut hampir mendekati 1 . Artinya kecenderungan berperilaku prososial antar kategori tidak terlalu berbeda jauh. Selain itu, terdapat perbedaan arah asosiasi antara perilaku prososial dengan pendapatan pada tabulasi silang dan rasio kecenderungan. Kemungkinan hal ini disebabkan perbedaan persentase antar kategori yang tidak berbeda jauh. Di samping itu, jika dilihat persentase perilaku prososial menurut pendapatan dengan penyebutnya jumlah populasi pada kategori variabel perilaku prososial, menunjukkan perilaku prososial tertinggi juga terjadi pada kelompok pendapatan sangat rendah.

\section{KESIMPULAN}

Penelitian ini berfokus dalam menentukan variabel-variabel yang memengaruhi perilaku prososial di Indonesia pada tahun 2017. Adapun kesimpulan yang dapat diambil dari penelitian ini yaitu: (1) Perilaku prososial penduduk Indonesia tahun 2017 didominasi oleh kategori kurang prososial, dimana 43,43 persen penduduk Indonesia tergolong prososial. Sedangkan sisanya 56,57 persen tergolong kurang prososial., (2) Berdasarkan hasil analisis inferensia dengan model regresi logistik biner, seluruh variabel yang dimasukkan 
ke dalam model terbukti berpengaruh secara signifikan terhadap perilaku prososial Indonesia pada tahun 2017., dan (3) Kecenderungan penduduk untuk berperilaku prososial lebih besar bagi mereka yang memiliki karaktersistik: puas terhadap hidupnya, perasaannnya senang, hidupnya bermakna, mempunyai sikap percaya dan toleran, berjejaring, berusia 41-64 tahun, dan berpendapatan sangat rendah.

Berdasarkan hasil penelitian tersebut, terdapat beberapa saran ataupun rekomendasi untuk berbagai pihak dalam rangka meningkatkan perilaku prososial penduduk Indonesia. Adapun saran-saran tersebut yaitu:(1) Masyarakat hendaknya meningkatkan perilaku prososialnya, mengingat pentingnya perilaku prososial dalam kehidupan bermasyarakat di Indonesia. Adapun cara meningkatkan perilaku prososial yaitu dengan cara meningkatkan kepuasan hidup, perasaan senang, kebermaknaan hidup, sikap percaya dan toleransi, dan jejaring sosial., dan (2) Masyarakat hendaknya meningkatkan modal sosial dengan meningkatkan hubungan dan komunikasi sosial antar masyarakat. Karena dengan meningkatnya modal sosial tersebut dapat mendorong rasa perhatian terhadap keadaan orang lain.,

\section{DAFTAR SINGKATAN}

$\begin{array}{ll}\text { Baznas } & \text { : Badan Amil Zakat Nasional } \\ \text { BPS } & \text { : Badan Pusat Statistik } \\ \text { CAF } & \text { : Charities Aid Foundation } \\ \text { Df } & \text { : Degree of freedom (derajat bebas) } \\ \text { IEP } & : \text { Institute dao Economics \& Peace } \\ \text { KRT } & : \text { Kepala Rumah Tangga } \\ \text { PDB } & \text { : Produk Domestik Bruto } \\ \text { SDSN } & \text { : Sustainable Development Solutions Network } \\ \text { SPTK } & \text { : Survei Pengukuran Tingkat Kebahagiaan } \\ \text { WGI } & \text { : World Giving Index } \\ \text { ZIS } & : \text { Zakat, Infak, dan Sedekah }\end{array}$

\section{DAFTAR PUSTAKA}

Badan Amil Zakat Nasional. (2017). Outlook Zakat Indonesia 2018. Jakarta: Badan Amil Zakat Nasional. Badan Amil Zakat Nasional. (2018). Outlook Zakat Indonesia 2019. Jakarta: Badan Amil Zakat Nasional.

Badan Pusat Statistik. (2012). Statsistik Modal Sosial 2012. Jakarta: Badan Pusat Statistik.

Badan Pusat Statistik. (2014). Statistik Modal Sosial 2014. Jakarta: Badan Pusat Statistik.

Badan Pusat Statistik. (2017). Indeks Kebahagiaan 2017. jakarta: Badan Pusat Statistik.

Badan Pusat Statistik. (2017). Statistik Modal Sosial 2017. Jakarta: Badan Pusat Statistik.

Bartlett, M. Y., \& DeSteno, D. (2006). Gratitude and Prosocial Behavior: Helping When It Costs Yous. Psychological Science, 17(4), 319-325.

Basti. (2007). Perilaku Prososial Etnis Jawa dan Etnis Cina. PSIKOLOGIKA: Jurnal Pemikiran dan Penelitian Psikologi, 12(23), 57-68.

Bekkers, R., \& De Graaf, N. D. (2005). Field od Education and Prosocial Behavior. Marktdag Sociologie. Brussels.

Bierhoff, H. W. (2002). Prosocial Behaviour. East Sussex, England: Psychology Press.

Brown, E., \& Ferris, J. M. (2007). Social Capital and Philanthropy: An Analysis of the Impact of Social Captial on Individual Giving and Volunteering. Nonprofit and Voluntary Sector Quarterly, 36(1), 85-99.

Cahyaningroom, E. A. (2015). Hubungan Antara Intensitas Menonton Tayangan Reality Show Televisi dengan Perilaku Prososial Remaja. Surakarta: Universitas Muhammadiyah Surakarta.

Charity Aid Foundation. (2013). World Giving Index 2013. CAF Publishing.

Charity Aid Foundation. (2014). World Giving Index 2014. CAF Publishing.

Charity Aid Foundation. (2015). World Giving Index 2015. CAF Publishing.

Charity Aid Foundation. (2016). World Giving Index 2016. CAF Publishing.

Charity Aid Foundation. (2017). World Giving Index 2017. CAF Publishing.

Charity Aid Foundation. (2018). World Giving Index 2018. CAF Publishing.

Cuadrado, E., Tabernero, C., \& Steinel, W. (2014). Motivational determinants of prosocial behavior: What do included, hopeful excluded, and hopeless excluded individuals need to behave prosocially? Motivation and Emotion, 39(3), 344-358.

Dovidio, J. F., Pilliavin, J. A., Schroeder, D. A., \& Penner, L. A. (2012). The Social Psychology of Prosocial Behavior. East Sussex: Psychology Press. 
Hosmer, JR., D. W., Lemeshow, S., \& Sturdivant, R. X. (2013). Applied Logistic Regression (Third kgatiso). Hoboken, New Jersey: John \& Sons, Inc.

Kau, M. A. (2010). Empati dan Perilaku Prososial Pada Anak. Jurnal INOVASI, 7(03), 1-5.

Kleinbaum, D. G., \& Klein, M. (2010). Logistic Regression: A Self-Learning Text (Third kgatiso). New York: Springer.

Lestari, D., \& Partini. (2015). Hubungan antara penalaran moral dengan perilaku prososial pada remaja. Indigenous : Jurnal Ilimah Psikologi, 13(2), 41-46.

Martin, K. M., \& Huebner, S. (2007). Peer Victimization and Prosocial Experiences and Emotional WellBeing of Middle School Students. Psychology in the Schools, 44(2), 199-208.

Muharram, Z. (2018). Pengaruh religiusitas, empati dan faktor demografi terhadap perilaku prososial peserta aksi bela islam 212. UIN Syarif Hidayatullah, Psikologi. Jakarta: UIS Syarif Hidayatullah.

Obsuth, I., Eisner, M. P., Malti, T., \& Ribeaud, D. (2015). The developmental relation between aggressive behaviour and prosocial behaviour: A 5-year longitudinal study. BMC Psychology, 3(16), 1-15.

Penner, L. A., Dovidio, J. F., Piliavin, J. A., \& Schroeder, D. A. (2005). Prosocial Behavior: Multilevel Perspectives. Annual Reviews Psychology, 56, 365-392.

Piff, P. K., Kraus, M. W., Cote, S., \& Cheng, H. (2010). Having less, giving more: the influence of social class on prosocial behavior. Journal of Personality and Social Psychology, 99(5), 771-784.

Putnam, R. D. (Motseleganyi). (2004). Democracies in Flux : The Evolution of Social Capital in Contemporary Society. New York, USA: Oxford University Press.

Schroeder, D. A., \& Graziano, W. G. (2015). The Field od Prosocial Behavior: An Introduction and Overview. MoD. A. Schroeder, \& W. G. Graziano, The Oxford Handbook of Prosocial Behavior (dits. 1-57). New York: Oxford University Press.

Suharyat, Y. (2009). Hubungan Antara Sikap, Minat dan Perilaku Manusia. Jurnal Region, I(3), 1-19.

Suyatni, S. (2017). Pergeseran nilai-nilai gotong royong masyarakat Desa Jelantik Lombok Tengah. NTB: UIN Mataram.

The Institute for Economic \& Peace. (2011). Global Peace Index 2011. Sydney: IEP Publishing.

The Institute for Economic \& Peace. (2012). Global Peace Index 2012. Sydney: IEP Publishing.

The Institute for Economic \& Peace. (2013). Global Peace Index 2013. Sydney: IEP Publishing.

The Institute for Economic \& Peace. (2014). Global Peace Index 2014. Sydney: IEP Publishing.

The Institute for Economic \& Peace. (2015). Global Peace Index 2015. Sydney: IEP Publishing.

The Institute for Economic \& Peace. (2016). Global Peace Index 2016. Sydney: IEP Publishing.

The Institute for Economic \& Peace. (2017). Global Peace Index 2017. Sydney: IEP Publishing.

Walgito, B. (2004). Pengantar Psikologi Umum/Bimo Walgito:Ed.IV. Yogyakarta: Andi Offset.

Wang, L., \& Graddy, E. (2008). Social Capital, Volunteering, and Charitable Giving. VOLUNTAS: International Journal of Voluntary and Nonprofit Organizations, 19, 23-42.

Weinstein, N., \& Ryan, R. M. (2010). When helping helps: Autonomous motivation for prosocial behavior and its influence on well-being for the helper and recipient. Journal of Personality and Social Psychology, 98(2), 222-224.

Yang, Y., Li, P., Fu, X., \& Kou, Y. (2017). Orientations to Happiness and Subjective Well-Being in Chinese Adolescents: The Roles of Prosocial Behavior and Internet Addictive Behavior. Journal of Happiness Studies, 1747-1762. 